GEOGRAFICKÝ ČASOPIS / GEOGRAPHICAL JOURNAL 70 (2018) 2, 179-194

https://doi.org/10.31577/geogrcas.2018.70.2.10

\title{
SLOVENSKO-RAKOUSKÁ PŘESHRANIČNÍ SPOLUPRÁCE POHLEDEM MÍSTNÍCH OBYVATEL A STAROSTŮ
}

\author{
Michal Šindelář, Milan Jeřábek* \\ * Masarykova univerzita, Př́rodovědecká fakulta, Geografický ústav, Kotlářská 2, 61137 Brno, Česká republika \\ michal-sindelar@centrum.cz, jerabek@sci.muni.cz
}

\begin{abstract}
The Slovak-Austrian cross-border cooperation in inhabitants and mayor's opinions

This paper focuses on the Slovak-Austrian borderland (the area of the Euroregion Pomoraví/Weinviertel/Záhorie). This research topic includes questions such as the relationship of the inhabitants of Slovakia and Austria with their neighbouring country, their attitude to the open border and the level of cross-border cooperation between the municipalities in this region. The topic of the paper was chosen due to its contemporary relevance, caused by the changes which occurred in the Slovak-Austrian borderland after the year 1989 (the borders were opened, Austria and then Slovakia became member states of the European Union, etc.). In addition, there is a lack of studies and research dedicated to this borderland. The research was carried out in the form of a survey in the municipalities of the Weinviertel/Záhorie Euroregion in autumn 2016. 176 interviews were conducted on the Slovak side of the region and 153 interviews were conducted on the Austrian side. The survey was supplemented with interviews with the mayors of selected municipalities.
\end{abstract}

Key words: borders, Slovak-Austrian borderland, cross-border cooperation and relationships, Pomoraví/Weinviertel/Záhorie Euroregion

\section{ÚVOD DO PROBLEMATIKY}

Slovensko-rakouská hranice je poměrně krátká (pouze $107 \mathrm{~km}$ ), ale ve vzájemných vztazích tvoří přidanou hodnotu blízkost obou metropolitních regionů, Bratislavy a Vídně. I když je dnes hranice plně prostupná, ve 20. století, když bylo Slovensko ještě součástí Československa, prošla československo-rakouská hranice do dnešních dnů výraznou proměnou a změnou funkce.

Poměrně prostupný hraniční úsek s Rakouskem se po druhé světové válce a zejména po roce 1948 díky nastolení nového sociálně-politického systému začal pomalu uzavírat, až se stal neprodyšným předělem mezi dvěma navzájem uzavřenými světy (Novotná et al. 2011). S tím souvisí i postupné omezení všech dosavadních kontaktů mezi oběma národy. Volný pohyb osob přes hranici byl zastaven, hranice začala být vojensky př́sně střežená a tato neprostupná bariéra, tzv. železná opona, oddělovala cca 40 let východní blok socialistických států od kapitalisticky vyvíjejících se zemí na západě. Tradiční vazby mezi Čechy, resp. Slováky a Rakušany byly silně narušeny (Havlíček 1999).

V roce 1989 byly otevřeny hranice, železná opona padla a z tzv. hranice uzavřené se stala hranice částečně otevřená, pohraniční region tak můžeme označit jako „most“ mezi sousedními státy (Jeřábek et al. 2004). V tomto režimu fungovala slovensko-rakouská hranice od roku 1989 přes osamostatnění se v roce 1993 po vstup do EU v roce 2004. Podle Martineze (1994) označujeme tento typ pohraničí jako pohraničí odcizené.

Po vstupu do EU bylo označováno slovensko-rakouské pohraničí jako kontaktní typ. Po roce 2007, kdy padla poslední omezení na slovensko-rakouské hranici, již 
mluvíme o hranici plně otevřené, pohraničí označujeme jako kooperační a předpokládáme tedy vznik a rozvoj různých forem přeshraniční spolupráce (Martinez 1994). Takový rozvoj pohraničních regionů, které jsou často i regiony periferními, patři mezi jedny z klíčových výzev regionální politiky jak na úrovni regionů a celého státu, tak i v rámci EU (Ptáćek et al. 2015).

Pokud se přeshraniční spolupráce mezi Slovenskem a Rakouskem týče, byla stejně jako v prŕípadě Česka velmi ovlivněna existencí železné opony, což znamenalo útlum politických, sociálních i ekonomických kontaktů, stejně jako nedostatečný rozvoj silniční i železniční infrastruktury. I když Bratislava a Vídeň představují dvě geograficky nejblíže situovaná hlavní města v EU, před rokem 1989 mezi nimi probíhala komunikace na minimální úrovni (Benč et al. 2013).

Vznik přeshraniční spolupráce a prvních přeshraničních struktur mezi Slovenskem a Rakouskem datujeme do bezprostředního období po pádu železné opony v roce 1989, kdy se v oblasti Záhorie, tehdy ještě součásti Československa, začaly navazovat kontakty s rakouskými obcemi různými jednorázovými ,pokusnými““ projekty v oblastech vzdělávání, spolupráce škol nebo kultury (Weixlbaumer 1999). Dále se rozvíjely individuální kontakty mezi občany nebo práce v zahraničí. Vznikla tedy určitá, avšak ne prŕiliš intenzivní hospodářská spolupráce, která za předešlého režimu probíhala jen velmi omezeně (Vaishar a Zapletalová 2005). Další impuls pro posílení přeshraniční spolupráce byl rok 1995, kdy Rakousko vstoupilo do EU, čímž mohlo být také slovensko-rakouské pohraničí zapojeno do předvstupního programu Phare CBC a programu INTERREG, což umožnilo čerpání evropských dotací. Právě možnost čerpání dotací byl jeden z hlavních důvodů pro vznik euroregionálních struktur ve slovensko-rakouském pohraničí. A konečně v roce 1999 byl založen Euroregion Pomoraví/Weinviertel/Záhorie (viz dále), který představuje trilaterální spolupráci mezi Českem, Rakouskem a Slovenskem.

Hlavní důvod opožděného rozvoje přeshraničních vztahů, i ve srovnání se sousedními státy střední Evropy, byl vývoj politické situace na Slovensku do roku 1998. Do té doby neexistovaly pro rozvoj přeshraniční spolupráce prŕżnivé podmínky, dokonce je možné konstatovat, že v některých prŕípadech byla tato spolupráce záměrně brzděná (Halás a Slavík 2001). Stála za tím silná pozice státu potlačujícího veškeré procesy, které spontánním způsobem vznikaly z místních nebo regionálních iniciativ, včetně přeshraničních.

I přes nepř́liš intenzivní přeshraniční vazby v 90 . letech 20 . století, mělo každopádně Slovensko pro Rakousko značný význam jako obchodní partner a investiční cíl (po Německu je Rakousko druhý největší investor na Slovensku). V době před vstupem Slovenska do EU je nutno zdůraznit ještě dva faktory. Zaprvé hrál $\mathrm{v}$ Rakousku roli strach ze ztráty pracovních míst v pohraničních oblastech, tudíž bylo v otázce volného pohybu pracovních sil vyjednáno až sedmileté omezující

\footnotetext{
${ }^{1}$ Přeshraniční spolupráce je definována jako více či méně institucionalizovaná spolupráce mezi přilehlými administrativními jednotkami (které jsou na nižší úrovni než stát), tj. regionální spolupráce přes státní hranici (Perkmann 2003). Přeshraniční spolupráce by se měla podporovat a rozvíjet, protože je považována za důležitý faktor úspěšného rozvoje pohraničních oblastí (Jeřábek et al. 2012). Přeshraniční spolupráce také představuje aktivity zaměřené na posilnění a podporu sousedských vztahů obyvatelstva a institucí na obou stranách společné hranice (Halás a Slavík 2001).

${ }^{2}$ Rakousko-slovenské vztahy byly z politického hlediska ovlivněné dějinami méně než vztahy česko-rakouské, např. Benešovy dekrety nehrají ve vzájemných vztazích velkou roli, protože dle sčítání lidu v roce 1930 se na Slovensku hlásilo k německé národnosti jen cca 157000 osob a i poválečný odsun proběhl bez větších excesů (Benč et al. 2013).
} 
přechodné období (stejně jako s Českem), které skončilo až v roce 2011. Za druhé, stejně jako $\mathrm{v}$ prrípadě Temelína, protestovali Rakušané proti slovenským jaderným elektrárnám Mochovce a Jaslovské Bohunice. Toto období také provázel strach Rakušanů ze zvýšené kriminality a ze znečištění životního prostředí (Weixlbaumer 1999).

Významný impuls pro přeshraniční spolupráci byl vstup Slovenska do EU v roce 2004 a možnost čerpání z evropských fondů. Větší rozvoj přeshraniční spolupráce mezi oběma státy znamenalo až spuštění programu přeshraniční spolupráce Slovenská republika - Rakousko na roky 2007 - 2013. V posledních letech není ale vidět nějaký podstatný pokrok v přeshraničních vztazích mezi Slovenskem a Rakouskem. Místní obyvatelstvo není př́liš aktivní a nad to se jedná o spíše uzavřenější region, kde jsou všichni na obou stranách hranice zaměstnáni svými problémy a nehledají príležitosti ani kontakty na druhé straně řeky Moravy (Fridrich a Zlochová 2009). Samotná řeka Morava představuje také podstatnou bariéru pro vzájemné vztahy, nebot' v současnosti je přemostěna pouze silnicemi nižších tříd mezi Hohenau a Moravským Svätým Jánom a mezi Angernem a Záhorskou Vsí. To je velký protiklad oproti česko-rakouskému pohraničí, které je protkané kromě silničních přechodů také hustou sítí cyklostezek. Fridrich a Zlochová (2009) dále poznamenávají, že určitá skepse a ,pomalost“ přichází v posledních letech z rakouské strany, na rozdíl od slovenské, která tlačí např. na budování nových hraničních přechodů.

Jak se tedy změnilo slovensko-rakouské pohraničí v posledních cca 25 letech? $\mathrm{Z}$ kdysi uzavřených hranic se staly hranice otevřené a $\mathrm{z}$ izolovaných lokalit se stal prostor vzájemných kontaktů. Odstranění železné opony vedlo k oživení obcí ležících v blízkosti hranice. Začaly se budovat nové hraniční přechody, obnovovala se dopravní infrastruktura, vznikaly obchody a různé služby, vzájemný obchod vzrostl, obyvatelé sousedních států se začali navštěvovat (i když o poznání méně ve srovnání s česko-rakouským pohraničím (Šindelář 2016)), obě země používají společnou měnu euro a i přes stále poměrně velké ekonomické rozdíly došlo k určité ekonomické konvergenci mezi oběma státy ${ }^{3}$.

Na tuto situaci pochopitelně reagovala vědecká komunita, a to jak slovenská, tak rakouská, přičemž vedle geografư (např. Drgoňa 2001, Kollár 2001, Slavík 2004, Spišiak 2004 a Halás 2005) svůj zájmem o socioekonomické změny v př́íslušném území projevují též sociologové řadou více či méně specifických témat. Zřejmě jako první zaměření se prosazuje studium národní identity pod vedením Piscové (1997), zahrnující mj. její proměnu v podmínkách Rakouska-Uherska, okolních států i integračních (unijních) procesů a mezinárodních struktur. Při studiu mentální hranice (Falt’an, ed. 2003) zaujme nejen vlastní problematika, ale také samotná etapizace sledování česko-rakouských vztahů (vč. oblasti Záhorie): 90. léta 20. století s důrazem na období před rokem 1989, pád železné opony a jeho dopady, „od očekávání k realitě“. Sledována byla rovněž mezinárodní/přeshraniční migrace, často pak s vazbou na trh práce (Fassmann a Münz 2002, Bahna 2009 a Sik a Surányi 2015). Na rozdíl od dosud zmíněných orientací se silně uplatňovaly rovněž komplexní prrístupy, a to v řadě projektů podpořených prostředky národními i zahraničními pod vedením L. Falt’ana. Jmenujme např. Eastern and Central Europe 2000, Interregión - Vznik nového teritoriálního společenstva či Cross-border

\footnotetext{
${ }^{3}$ Při zohlednění kupní síly vzrostl HDP na osobu na Slovensku z 35 \% rakouské hodnoty v roce 1995 na 57 \% $\mathrm{v}$ roce 2012 .
} 
Interregional Cooperation and Slovakia. Rakouská „stopa“ se týká např. projektu Priemyselný park Jarovce-Kittsee a Bratislavský región - Viedeň.

Zmapování a vývoj, resp. budoucí možnosti současné přeshraniční spolupráce byly jedním z cílů tohoto výzkumu. Dalším cílem bylo zjistit, jak se obyvatelé sousedních zemí navzájem vnímají a jaký projevují zájem o sousední zemi, jako je napřr. důvod a počet návštěv nebo např. asociace, se kterými si místní obyvatelé sousední zemi spojují.

\section{EUROREGION POMORAVÍ / WEINVIERTEL / ZÁHORIE}

Ve srovnání např. s česko-německým pohraničím, začala spolupráce mezi Českem a Rakouskem a Slovenskem a Rakouskem o poznání později ${ }^{2}$. První významnější dokument týkající se problematiky přeshraniční spolupráce s názvem $\mathrm{O}$ rozvoji spolupráce mezi regiony Weinviertel, Jihomoravským krajem a oblastí Záhorie byl podepsán a odsouhlasen až v roce 1997. Smlouva prezentovala obecná ustanovení o přeshraniční spolupráci a byla prvním krokem, který vedl $\mathrm{k}$ vytvoření přeshraničního subjektu, tj. euroregionu. $\mathrm{Na}$ základě této deklarace však nebyla vytvořena žádná přreshraniční struktura, ale jen neformální pracovní společenství. Až o dva roky později, v roce 1999, byla uzavřena dohoda o založení přeshraničního sdružení s názvem Euroregion Pomoraví/Weinviertel/Záhorie.

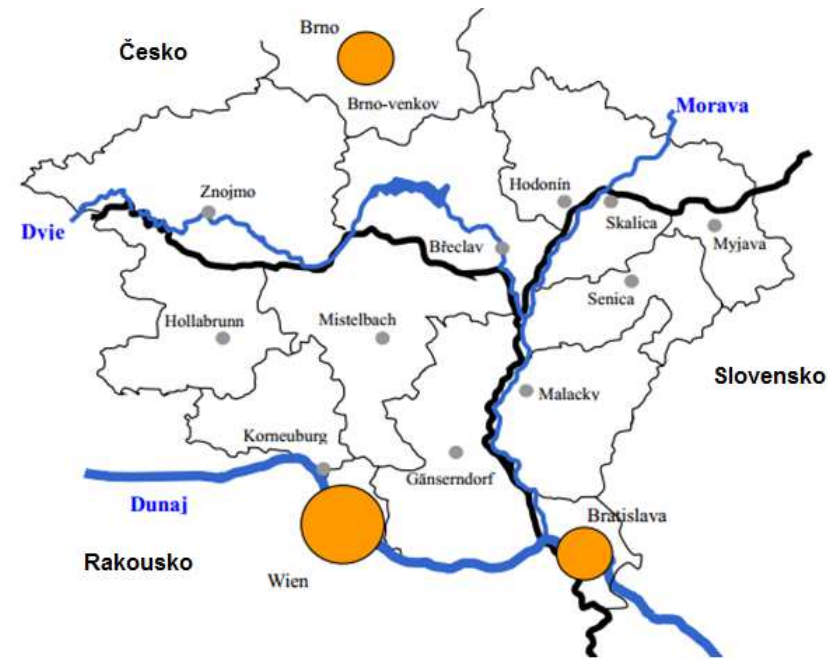

Obr. 1. Administrativní členění Euroregionu Pomoraví/Weinviertel/Záhorie

Zdroj: Regionalverband Europaregion Weinviertel (2015).

Studovaný euroregion je rozprostřen kolem cca $240 \mathrm{~km}$ dlouhé hranice mezi Českem, Rakouskem a Slovenskem (obr. 1). Na českém území je tvořen členskými obcemi z okresů Brno - město, Brno - venkov, Břeclav, Hodonín, Znojmo, Vyškov a Blansko. Na Slovensku k euroregionu patří okresy Malacky, Myjava, Senica a Skalica. V Rakousku je vymezen politickými okresy Gänserndorf, Hollabrunn,

\footnotetext{
${ }^{4}$ Např. Euroregion Neisse-Nisa-Nysa (DE-CZ-PL) byl založen již v roce 1991 a Euroregion Elbe/Labe (DE-CZ) v roce 1992. Více např. Jeřábek et al. (2012).
} 
Korneuburg a Mistelbach. Další informace jako je počet obyvatel, rozloha a počet obcí jsou zobrazeny v tab. 1. Na rozdíl od jiného euroregionu mezi Českem a Slovenskem, jako je např. Euroregion Bílé/Biele Karpaty, jehož členem jsou všechny obce ve vymezeném regionu, je členství obcí v Euroregionu Pomoraví/Weinviertel/ Záhorie dobrovolné a tedy ne všechny obce ve vymezeném území do euroregionu př́sluší.

Mezi hlavní činnosti euroregionu patří koordinace hospodářského, sociálního a kulturního rozvoje, poskytování poradenství obcím či soukromým osobám v oblasti zpracování projektů, snaha přispívat ke sbližování a vzájemnému poznávání lidí a jejich kultur nebo organizování pracovních setkání, seminářu či různých akcí v obcích patrících k euroregionu.

\section{VLASTNÍ VÝZKUM}

Prezentovaný výzkum týkající se přeshraniční spolupráce, který proběhl na podzim roku 2016, byl realizován dvěma formami: zaprvé dotazníkovým šetřením s celkovým počtem 329 respondentů (176 rozhovorů na Slovensku a 153 v Rakousku). Hlavním cílem výzkumu bylo zjištění odpovědí na otázky:

- Jak jsou místní obyvatelé spokojeni s životem ve studovaném regionu?

- Jak se navzájem vidí obyvatelé slovenského a rakouského pohraničí?

- Navštěvují místní obyvatelé sousední stát? Jak často a proč?

- Kde vidí problémy, resp. možnosti pro další rozvoj regionu?

Tyto a další otázky byly analyzovány, vyhodnoceny a okomentovány. Tato stěžejní část výzkumu byla doplněna čtyřmi ř́izenými rozhovory se starosty obcí ve studovaném regionu. Jejich výpovědi uvádíme jako doplněk k jednotlivým hodnocením.

Dotazníkové šetření probíhalo v obcích, které jsou členy Euroregionu Záhorie (SK) a Weinviertel (AT). Na obou stranách hranice byli respondenti vyhledáváni a dotazováni spíše v populačně větších městech $\mathrm{s}$ tím, že tato města představují přirozenou spádovou oblast pro okolní obce, jejichž obyvatelé jsou ve výzkumu taktéž zahrnuti. Na slovenské straně probíhalo dotazníkové šetření zejména ve Skalici, Senici, Stupavě a v Malackách, na rakouské straně v Mistelbachu, Gänserndorfu, Wolkersdorfu a v Korneuburgu. Respondenti byli vybíráni na základě kombinace náhodného a kvótního výběru, tj. podle pohlaví, věku, vzdělání a místa bydliště (viz tab. 2). Cílem bylo získat takový soubor respondentů, aby jednotlivé kvóty přibližně odpovídaly zastoupení daných kategorií v populaci. Metodika a tvorba dotazníku vycházely ve velké míre z výzkumů, které již v pohraničních územích proběhly v minulých letech (viz Jeřábek et al. 2004, Vaishar et al. 2009, Dokoupil et al. 2012 a Kowalke et al. 2012).

Tab. 1. Základní informace o Euroregionu Pomoraví

\begin{tabular}{lccc}
\hline Stát & Rozloha v km² & Počet obyvatel $\mathrm{v}$ tis. & Počet obcí \\
\hline $\mathrm{CZ}$ & 5135 & 735 & 59 \\
$\mathrm{SK}$ & 2300 & 172 & 79 \\
$\mathrm{AT}$ & 4090 & 245 & 86 \\
Celkem & 11525 & 1152 & 224 \\
\hline
\end{tabular}

Zdroj: Regionalverband Europaregion Weinviertel (2015) a ČSÚ (2015). 
Tab. 3 znázorňuje rozdělení populace ve spolkové zemi Dolní Rakousy a v Trnavském kraji podle věku a vzdělání za rok 2015, resp. 2011. Pokud tato data srovnáme s údaji dotazovaných respondentů, vidíme, že v obou státech bylo dotazováno více osob s vysokoškolským vzděláním než jaký je jejich poměr v populaci. Také jsou v souboru respondentů více zastoupeni lidé v mladších věkových skupinách, s obyvateli ve věkové skupině $65+$ bylo provedeno méně rozhovorů než odpovídá demografické struktuře jednotlivých regionů. Poměr mužů a žen je ve všech regionech poměrně vyrovnaný, mírně převažují ženy a stejná byla i struktura respondentů v šetření, kdy cca $52 \%$ dotazovaných byly ženy.

Tab. 2. Rozdělení oslovených respondentů dle jednotlivých kategorií

\begin{tabular}{ccccc|ccccc}
\hline \multicolumn{4}{c}{ Rakušané (početnost) } & \multicolumn{5}{c}{ Slováci (početnost) } \\
\hline Věk (let) & Zš & Vyučen/a & Sš & Vš & Věk (let) & Zš & Vyučen/a & Sš & Vš \\
$15-34$ & 5 & 12 & 22 & 18 & $15-34$ & 16 & 23 & 22 & 24 \\
$35-49$ & 6 & 15 & 15 & 18 & $35-49$ & 9 & 20 & 17 & 6 \\
$50-64$ & $\mathrm{x}$ & 14 & 7 & 7 & $50-64$ & $\mathrm{x}$ & 11 & 12 & 7 \\
$65+$ & 3 & 4 & 3 & $\mathrm{x}$ & $65+$ & 2 & 5 & 3 & $\mathrm{x}$ \\
\hline
\end{tabular}

Zdroj: vlastní zpracování.

Tab. 3. Věková a vzdělanostní struktura obyvatel ve spolkové zemi Dolní Rakousy pro rok 2015 a v Trnavském kraji pro rok 2011

\begin{tabular}{ccccc|ccccc}
\hline \multicolumn{4}{c|}{ Rakušané (početnost) } & \multicolumn{5}{c}{ Slováci (početnost) } \\
\hline Věk (let) & Ž̌ & Vyučen/a & Sš & V̌s & Věk (let) & Žs & Vyučen/a & Sš & Vš \\
$15-34$ & 3 & 10 & 7 & 3 & $15-34$ & 6 & 11 & 7 & 3 \\
$35-49$ & 4 & 12 & 8 & 4 & $35-49$ & 9 & 13 & 8 & 4 \\
$50-64$ & 5 & 11 & 8 & 3 & $50-64$ & 7 & 8 & 6 & 2 \\
$65+$ & 4 & 3 & 7 & 2 & $65+$ & 6 & 5 & 5 & 1 \\
\hline
\end{tabular}

Zdroj: Land Niederösterreich /Zahlen und Fakten/Bildung (2015) a ŠÚ SR (2015).

\section{VÝSLEDKY VÝZKUMU}

Samotný dotazník byl členěn do tří okruhů. V první části byla zjišt’ována stabilita obyvatelstva. Zkoumáno bylo, jak dlouho v regionu obyvatelé žijí, zda, prríp. jak často se stěhují, jak jsou spokojeni s životem v regionu a jaký je jejich celkový vztah $\mathrm{k}$ oblasti, tj. regionální identita. Ve druhé sadě otázek byly hodnoceny slovensko-rakouské občanské vztahy. Bylo zjišt’ováno, zda místní obyvatelé navštěvují sousední zemi, jak často a proč, jak hodnotí otevření hranic a jaké jsou podle nich další možnosti pro rozvoj regionu nebo, naopak, problémy. Tématem třetí části byla přeshraniční spolupráce a existence euroregionu. V tomto bloku otázek šlo napřr. o povědomí o existenci euroregionu a o aktivní, resp. pasivní účast na přeshraničních aktivitách.

Pokud se týká stability obyvatelstva ve studovaném regionu, jak na slovenské, tak i na rakouské straně hranice je možné většinu obyvatelstva (cca dvě třetiny v obou zemích) označit za starousedlíky, kteří v obci, kde žijí, strávili celý život. Dalších zhruba desetina respondentů uvedla, že žili i někde jinde, např. kvůli studiu nebo zaměstnání, a pak se do rodné oblasti vrátili. Výhodou regionu je blízkost 
Bratislavy a Vídně, protože nedochází $\mathrm{k}$ tak velké emigraci především mladých lidí, kteř́ by vzdálenější region, např. kvůli studiu na VS, opustili. Zbylá část respondentů, zhruba pětina všech dotazovaných, uvedla, že se do regionu přistěhovala. V Rakousku se do pohraničních obcí a měst stěhovali zejména obyvatelé Vídně, taktéž na Slovensku se respondenti z velké míry stěhovali v rámci blízkých regionů (zazněla města jako Trnava, Nitra, Bratislava a pod.).

$\mathrm{K}$ další otázce více než čtyři pětiny Rakušanů uvedly, že se rozhodně nechtějí stěhovat pryč. Ostatní uvažují o stěhování zejména do Vídně za městským životem nebo do Alp za atraktivnější prŕírodou. Důvody jsou pracovní př́iležitosti nebo rodinné záležitosti. Na druhé straně, na Slovensku uvažuje o vystěhování se cca třetina dotazovaných. Hlavním důvodem je málo pracovních př́ležitostí a nízké mzdy a tito lidé uvažují nad stěhováním do nějakého většího města v rámci Slovenska, nebo do Vídně, do Prahy a často zaznělo i Spojené království. Respondenti, kteří uvedli, že se stěhovat nehodlají, deklarovali, že vnímají region veskrze pozitivně. Obr. 2 zobrazuje odpovědi na otázku, co vás poutá nejvíce k místu bydliště. Odpovědi Slováků a Rakušanů se prŕiliš neliší, pokud převažující odpověd’ bydlení u Rakušanů znamená to samé jako odpověd' ,zvyk bydlet v tomto kraji“ u Slováků. Dále hraje hlavní roli rodina, blízkost prríbuzných a práce.

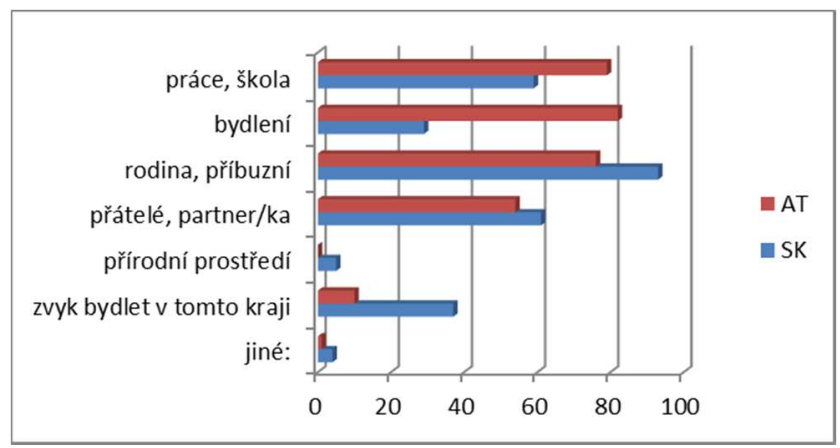

Obr. 2. Co nejvíce poutá k místu bydliště (početnost odpovědí)

Poznámka: byla možnost uvést více odpovědí Zdroj: vlastní zpracování.

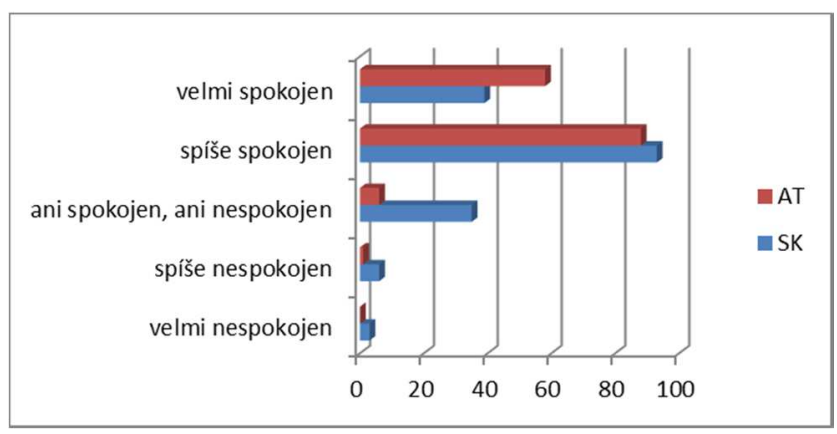

Obr. 3. Celková spokojenost s životem ve studované oblasti (početnost odpovědí) Zdroj: vlastní zpracování 
Výsledky na otázku, jak jsou respondenti celkově spokojeni s životem v tomto regionu, zobrazuje obr. 3. Poznatky jsou určitě pozitivní, i když jsou Slováci spokojeni o něco méně. Rakušané by přivítali více pracovních míst, aby nebylo nutné dojíždět za prací do Vídně, která je ale na druhou stranu dobře dostupná sítí SBahn a propracovanou záchytnou sítí $\mathrm{P}+\mathrm{R}$ parkovišt'. Slováci v oblasti Skalice uváděli, že jsou s životem velmi spokojeni a rozhodně by nechtěli žít jinde, skeptičtější byli obyvatelé Malacek a Senice, a to zejména s ekonomickou úrovní jak jejich samotných, tak celého místa bydliště. Naopak, stížnosti na špatnou dopravní situaci a chybějící obchvaty měst zde, na rozdíl od obyvatel v česko-rakouském pohraničí, (Šindelář 2016) nezazněly.

V následující otázce byly zjišt'ovány první tři asociace, které se respondentům vybaví, pokud se řekne Slovensko, resp. Rakousko. Ne všichni respondenti, zejména v Rakousku, uvedli tři pojmy, proto součet odpovědí nedává sumu počtu dotazovaných krát trri. Obyvatelé slovenského př́íhraničí si Rakousko spojují s asociacemi jako Vídeň, vysoká životní úroveň, vyšší platy, čistota a Alpy. Rakušané naopak vidí Slovensko v pojmech, jakými jsou sousední stát, Bratislava, levná pracovní síla, gastarbeiteři a levné nákupy, resp. nízké ceny. Asociace, které uvedli Rakušané ke Slovensku, byly hodně podobné těm, které zazněly ve výzkumu v pomezí Jihočeského kraje a Horního Rakouska (Cizek 2010). Asociace mezi Jihomoravským krajem a Dolním Rakouskem se ale jeví o něco pozitivnější (viz např. Jeřábek et al. 2017). Všechny asociace, které byly vyřčeny pětkrát a více jsou zachyceny na obr. 4.

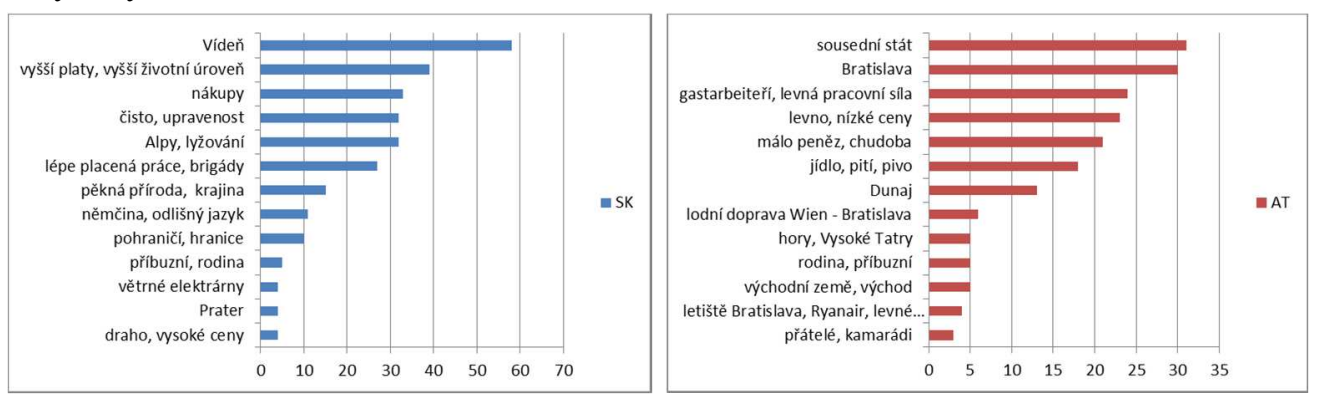

Obr. 4. Nejčastěji se vyskytující asociace, pokud se řekne Slovensko, resp. Rakousko (početnost odpovědí)

Zdroj: vlastní zpracování.

Dále byly hodnoceny slovensko-rakouské občanské vztahy (obr. 5), což víceméně souvisí i s komentáři u předešlé otázky. Většina Slováků i Rakušanů je ohodnotila stupněm spíše dobré nebo ani dobré, ani špatné. Kategorii ani dobré, ani špatné vybrali ale také respondenti, kteří se o dané téma nezajímají a na vzájemné vztahy nemají žádný názor. Jinak ale vzájemné vztahy nejsou zatížené historickými reminiscencemi jako v př́padě Česka, se kterým si mnoho Rakušanů dodnes spojuje Benešovy dekrety, nucený odsun nebo problematiku jaderných elektráren. Ani oslovení starostové nevidí v obecné rovině nějakou zásadní překážku vzájemných vztahů. Vnímání sousedního národa ovlivňuje přeshraniční vztahy a vazby a pokud je většina respondentů hodnotí dobře, mohlo by to vést $\mathrm{k}$ budoucí intenzivnější spolupráci. 
Z následující sady otázek vyplynulo, že polovina Rakušanů navštěvuje Slovensko a dvě třetiny Slováků navštěvuje Rakousko, což na to, že výzkum probíhal v obcích ležících nedaleko hranice, není příliš vysoký podíl. Obr. 6 znázorňuje četnost návštěv v sousední zemi. A i když jsou v tomto grafu zobrazeny jen odpovědi respondentů, kteří navštěvují sousední stát, je zřejmé, že vzájemné návštěvy jsou poměrně málo časté. Rakušané navštěvují sousední zemi jednou/dvakrát za rok nebo méně často, až poté následuje odpověd' cca jednou za čtvrtletí. Slováci jsou aktivnější, ti navštěvují Rakousko také nejčastěji jednou/dvakrát za rok, odpověd' čtvrtletně nebo méně často zazněla nastejno.

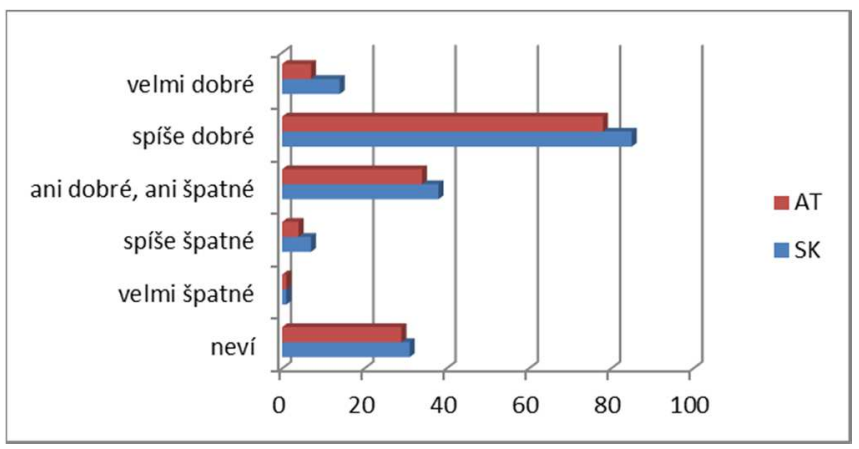

Obr. 5. Hodnocení slovensko-rakouských občanských vztahů (početnost odpovědí) Zdroj: vlastní zpracování.

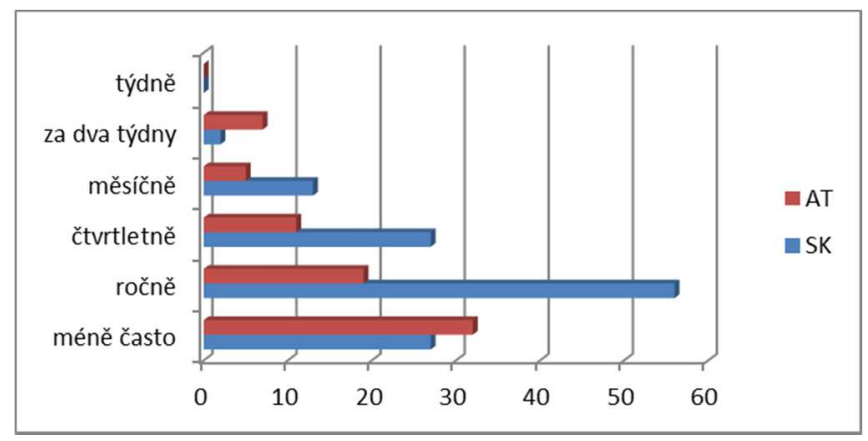

Obr. 6. Frekvence návštěvy Slovenska, resp. Rakouska (početnost odpovědí)

Zdroj: vlastní zpracování.

Rakušané míří nejčastěji do blízkého příhraničí, eventuálně do Bratislavy, stejně tak i Slováci rádi jezdí do Vídně a jejího okolí. Občas i projíždějí přes Rakousko směrem na jih, do Itálie nebo do Chorvatska. Hlavní důvody pro návštěvu sousední země jsou v př́padě Rakušanů hlavně nákupy a využití služeb, jejichž cenová hladina je oproti Rakousku stále nižší, a dále se objevuje i odpověd' výlet a trávení volného času, ale zejména $\mathrm{v}$ Bratislavě a nikoliv ve studovaném regionu. Napřr. historické město Skalica by určitě mělo rakouským turistům co nabídnout, dle odpovědí slovenských dotazovaných sem ale jezdí Rakušané velmi zř́idka. Naopak, chváleno bylo od několika rakouských dotazovaných lodní spojení po Dunaji mezi 
Vídní a Bratislavou. Několik Slováků také uvedlo, že jezdí do Rakouska kvůli práci nebo studiu, což je odpověd', kterou nevybral jediný Rakušan.

Třetí a nejobsáhlejší téma dotazníkového šetření je věnováno přeshraniční problematice. Čtvrtina Rakušanů a více než polovina Slováků uvedly, že naprosto souhlasí s tvrzením, že obec, ve které žijí, leží v pohraničí a další čtvrtina respondentů z Rakouska a pětina ze Slovenska s tímto výrokem souhlasí částečně. To znamená, že místní obyvatelé, i když ne v takové míře jako v česko-rakouském pohraničí, jsou si existence státní hranice vědomi. Také starostové souhlasí s výrokem, že jejich obec leží v pohraničí, ale přesto se orientují spíše směrem k městům a centrům státu, ve kterém daná obec leží, a nikoliv směrem přes státní hranici.

Zhruba dvě třetiny dotazovaných Rakušanů a Slováků označily region, kde žijí, jako oblast $\mathrm{s}$ velkým rozvojovým potenciálem a možnostmi oproti cca třetině responedntů, kteří ho označili za periferní a zaostávající území. Zřejmě by se dalo tvrdit, že Rakušané se s regionem identifikují, ale jsou orientovaní směrem na Vídeň, at' už kvůli práci nebo kulturnímu vyžití. I na Slovensku by si někteří dotazovaní přáli, aby byl region atraktivnější a bohatší, na druhou stranu nezaznělo, co konkrétně by se mělo změnit.

Tématem další otázky byl postoj obyvatel k prostupnosti státní hranice (obr. 7). Výsledky by se daly označit za velmi dobré. Více než čtyři pětiny respondentů v Rakousku a dokonce každý devátý respondent na Slovensku odpověděli, že otevření hranice je pro jejich region určitě nebo spíše pozitivní. Vyloženě negativních reakcí zaznělo jen velmi málo. Objevují se názory, a sice v obou státech, že určitá kontrola hranic je žádoucí. Podle Rakušanů usnadňuje současný stav přeshraniční kriminalitu a pokud by fungovaly hraniční kontroly, byla by jimi eliminována. Často byl zmíněn i současný problém s imigranty, jejichž cílem bylo/je často i Rakousko. Místní obyvatelé se k této problematice vyjadřovali spíše negativně a neustálý tok imigrantů by měl být podle nich důvodem k částečným kontrolám státní hranice.

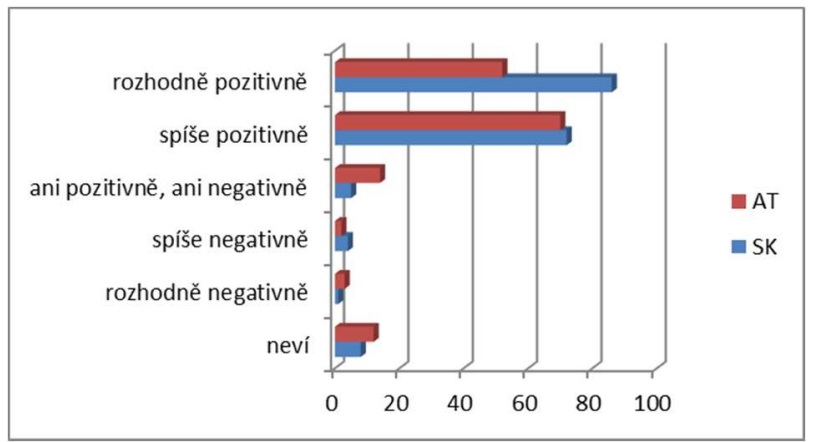

Obr. 7. Osobní postoj k plně prostupné a otevřené státní hranici (početnost odpovědí)

Zdroj: vlastní zpracování.

Obr. 8 zobrazuje odpovědi na otázku: Jak často se setkáváte se Slováky, resp. Rakušany, a prohodíte s nimi alespoň několik vět? Jak rakouští, tak slovenští respondenti, reprezentující zdejší populaci, se navzájem potkávají poměrně málo. Souvisí to i s tím, že tamní občané sousední stát navštěvují celkem zríidka. Zdaleka nejvíce zazněla odpověd', že se s občany sousedního státu vůbec nepotkávají a že spolu nekomunikují. 
Bohužel přeshraničních aktivit v regionu moc neprobíhá. Rozhodně se zde nepodařilo vytvořit nic, co by se jen vzdáleně mohlo nazvat přeshraničním společenstvím (Zich, ed. 2003). O existenci takových aktivit ví přibližně třetina respondentů, a to jak v Rakousku, tak na Slovensku. V další otázce, ve které bylo zjišt'ováno, o jakou konkrétní oblast se jedná, byla nejčastější odpověd' kultura, vzdělání a sport. Mezi další odpovědi patřila doprava a hospodářství. Výsledky trochu zkresluje skutečnost, že například v Holíči nebo ve Skalici obyvatelé o přeshraničních aktivitách vědí a dle jejich slov je i navštěvují, nicméně jedná se o spolupráci s českým Hodonínem a nikoliv s rakouskými obcemi. Naopak, těsně u rakouských hranic, v Malackách nebo ve Stupavě, téměř nikdo jakoukoliv spolupráci s Rakouskem nezmínil. Ani Rakušané neuvedli nějaký konkrétní př́klad spolupráce s blízkými slovenskými obcemi. Pokud už se někdo nějaké přeshraniční akce zúčastní, pak jako divák a značně nepravidelně. Aktér ${ }^{5}$, který by se v regionu zasazoval o navazování kontaktů s podobnými aktéry v zahraničí, se ve výzkumu neobjevil. Výsledky tohoto šetření poukazují na malou aktivitu obyvatel tohoto euroregionu ve vztahu k přeshraničním činnostem.

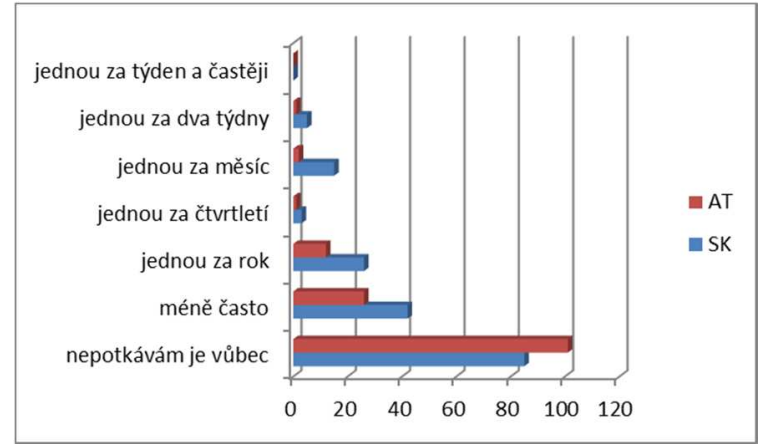

Obr. 8. Frekvence setkávání se Slováky, resp. Rakušany (početnost odpovědí)

Zdroj: vlastní zpracování.

Na obecnou otázku, zda respondenti znají pojem euroregion, odpovědělo kladně téměř dvě třetiny Rakušanů a cca tři čtvrtiny Slováků. Na konkrétnější otázku, zda vědí, že žijí v euroregionu, a zda by mohli uvést jeho název, odpověděla správně nebo částečně správně pouze asi pětina respondentů $v$ Rakousku a ještě o něco méně na Slovensku. Nejčastěji si respondenti pletli pojem euroregion s územím celé EU nebo se státy eurozóny či s jinými názvy blízkých mikroregionů.

Poslední otázka byla otevřená a dotazovaní se mohli vyjádřit k problémům nebo naopak k možnostem, které rakousko-slovenské pohraničí má, s ohledem na budoucí rozvoj. Nejčastější charakteristiky jsou takové, že se jedná o oblast s pěknou prírodou a klidem a že jsou vztahy Slovenska s Rakouskem na dobré úrovni a zlepšují se. Na druhé straně je zde nedostatek zejména kvalifikovaných pracovních míst (za kterými se dojíždí do Vídně nebo Bratislavy) a problém se znalostí jazyka, tj. komunikační bariéra. Podobné komentáře zazněly i od starostů. Od nich byla dále

\footnotetext{
${ }^{5}$ Tzv. aktéři jsou podporovatelé přeshraniční spolupráce v pohraničních regionech. Jejich motivace ke spolupráci přes hranice je rủzná, ale převažuje zájem o další rozvoj kontaktů, vztahů a spolupráci (Pleskot 2005).
} 
kritizována př́lišná byrokracie a rozdílné postupy při plánování, eventuálně schvalování podpory pro nějaký přshhraniční projekt.

V následujících dvou tabulkách (tab. 4 a 5) jsou přehledně zpracovány problémy a možnosti z výpovědí respondentů, kteři měli určit silné a slabé stránky regionu, ve kterém žijí.

Tab. 4. Problémy a možnosti přeshraničního regionu z pohledu Slováků

\begin{tabular}{ll}
\hline Problémy & Možnosti \\
\hline $\begin{array}{l}\text { Komunikační sít' - málo hraničních přechodů } \\
\text { a obchvatů }\end{array}$ & Rozvoj cestovního ruchu \\
Jazykový problém & Spolupráce v oblasti kultury \\
Problém s migranty a ilegálním přechodem hranic & Zlepšení vzájemných vztahů \\
Nízké mzdy a obecně málo peněz na Slovensku & Dorovnání ekonomické úrovně Rakouska \\
Další zaostávání této oblasti na rozdíl od aglomerace & $\begin{array}{l}\text { Společný trh práce, nabídka pracovních míst a brigád } \\
\text { Bratislavy, resp. Vídně }\end{array}$ \\
\hline
\end{tabular}

Zdroj: vlastní zpracování.

Tab. 5. Problémy a možnosti přeshraničního regionu z pohledu Rakušanů

\begin{tabular}{ll}
\hline Problémy & Možnosti \\
\hline Neznalost jazyka a problém s komunikací (angličtina & Vzájemná spolupráce přinese ekonomický rozvoj \\
je cesta) & oběma státům \\
Málo pracovních míst v regionu & Pomalé vyrovnávání obou ekonomik \\
Vzrůstající nacionalismus a ilegální migrace & Intenzivnější a užší spolupráce \\
Vzrůstající kriminalita & Lepší infrastruktura \\
Ekonomická rozdílnost & Mít k dispozici více informací o sousedním státu \\
\hline
\end{tabular}

Zdroj: vlastní zpracování.

Ze shrnutí rozhovorů se starosty vyplynulo, že po pádu železné opony byly snahy o vybudování spolupráce intenzivnější než dnes. Obecně řečeno, v rakouských převážně menších obcích není spolupráce se slovenskými, resp. českými obcemi na vysoké úrovni. O poznání intenzivnější je spolupráce mezi českým a rakouským pohraničím v rámci Euroregionu Pomoraví (Śindeláŕ 2016), jako prríklad lze uvést třeba společnou kandidaturu Retzu a Znojma na spolupořádání Dolnorakouské zemské výstavy v roce 2021.

Ale například největší město v oblasti, Mistelbach, nemá ale žádné významné vazby na českou ani slovenskou stranu, nebot' již leží od hranic relativně daleko a zároveň je poměrně silně orientováno na Vídeň. Ani ve slovenských obcích není spolupráce s rakouskými partnery významná. Za zmínku stojí spolupráce Holíče a města Skalica s českým Hodonínem, který ale leží mimo studovaný region. V malých obcích přseshraniční spolupráce prakticky neprobíhá.

Jako největší problém se ukazují jazyková bariéra a ekonomická rozdílnost. Rakouští starosté by si přáli intenzivnější komunikaci se slovenskou a českou stranou, obávají se ale, že ani v budoucnu to nebude o moc lepší. Jako problematický je viděn i aktuální politický vývoj v Evropě. Pokud bude policie hranici intenzivněji kontrolovat, bude to pro přeshraniční spolupráci kontraproduktivní, zní jeden $\mathrm{z}$ názorů. $\mathrm{Na}$ druhou stranu část obyvatel ve všech třech zemích souhlasí s minimálně namátkovými kontrolami na hranicích. 
Starostové se často navzájem i osobně znají, ale uvádějí, že není mnoho možností, kde se potkat a vyměňovat si informace a názory. Celkově vzato jsou ale projekty, které již byly realizovány (zejména prostřednictvím tzv. Fondu malých projektů), hodnoceny kladně a vzájemná spolupráce je popisována jako dobrá nebo velmi dobrá. Dále zazněly výtky a stížnosti na velké odlišnosti mezi českým, resp. slovenským a rakouským politickým, právním a správním systémem, což vede k obtížím při realizaci přeshraničních aktivit, na které je potřeba vynaložit hodně času. Co se byrokracie týče, o poznání větší náročnost i s následnými kontrolami a audity projektů je dle starostů na rakouské straně. Zaznívaly i názory, že na mnohé projekty by se finance sehnat i podařily, ale z důvodu až nesmyslně či složitě zadaných kritérií určitých výzev, jejichž administrativní náročnost je vysoká, se projektů obce pak ani nezúčastní a o dotace nepožádají.

Dle většiny starostů je přeshraniční spolupráce ve vnímání místních obyvatel celkem nízká a iniciativa většinou přichází od místních angažovaných lidí, od škol nebo od různých zájmových spolků. Takových aktérů, kteří by vyvíjeli aktivitu a komunikovali s podobnými aktéry na druhé straně hranice, je prý v regionu nedostatek.

Z rozhovorů ve zkratce vyplynulo, že jsou vzájemné vztahy dobré nebo spíše dobré, avšak vzhledem $\mathrm{k}$ jazykové bariéře a administrativním odlišnostem zůstává přeshraniční spolupráce na nízké úrovni a v krátkodobém horizontu několika let nejsou nějaké významné změny očekávány.

\section{ZÁVĚR}

Slovensko-rakouské pohraničí se od roku 1989 diametrálně proměnilo. Z izolované periferní oblasti rozdělené železnou oponou se stal otevřený prostor pro nejrůznější vazby a kontakty na hranici ,staré“" a „nové“ země EU bez hraničních kontrol a jakýchkoliv omezení. Navázány či obnoveny byly četné kontakty nejrůznějšího charakteru. Zřejmě zásadní roli ve sbližování a propojování tohoto regionu sehrála (finanční) podpora ze strany EU směřující k utváření jednotného (společného) přeshraničního regionu prostřednictvím příslušného operačního programu INTERREG.

Příspěvek se zaměřuje na výsledky dotazníkového šetření z podzimu roku 2016 v rakouské i slovenské části euroregionu, jehož cílem bylo zjistit pohled Slováků a Rakušanů bydlících v těsné blízkosti slovensko-rakouské hranice v rámci Euroregionu Pomoraví/Weinviertel/Záhorie na úroveň současných vzájemných vztahů, na otevřenou státní hranici, na pohraniční region, který obývají, a na Rakousko, resp. Slovensko jako na sousední zemi. První sada otázek se týkala stability obyvatelstva, následovaly otázky ohledně pohledu obyvatel na Rakousko, resp. na Slovensko, a třetí část se věnovala přeshraniční problematice a existenci euroregionu.

Z odpovědí provedeného dotazníkového šetření vyplývá, že slovensko-rakouské vztahy jsou poměrně dobré a nezatížené nějakou skutečností, která by brzdila nebo bránila dalšímu rozvoji. Taktéž problematika otevření hranic a její prostupnost jsou kladně hodnoceny. Jen dosavadní přseshraniční spolupráce (především na obecní úrovni) není, na rozdíl od spolupráce s Českem, např. s Hodonínem, moc intenzivní.

Lze tvrdit, že většina respondentů je s životem ve slovensko-rakouském pohraničí spokojena. Jako silná stránka byla uváděna př́roda a klid, jako negativum byl zmíněn nedostatek pracovních míst (v Rakousku) a nízké mzdy (na Slovensku), 
což vede zejména na Slovensku k odchodu z regionu (často jako cíl zazněla Bratislava, Vídeň, Praha nebo i Spojené království). Bohužel ekonomická konvergence mezi Slovenskem a Rakouskem neprobíhá příliš rychle a i když došlo k určitému posunu, rozdíly přetrvávají.

$\mathrm{K}$ dalším důležitým poznatkům patří zjištění, že většina obyvatel pohraničí navštěvuje sousední zemi poměrně zrrídka, a když už dojde k návštěvě, hlavním důvodem bývají nákupy, využití služeb nebo výlet a trávení volného času. Asi nejvýznamnější problém, který brání intenzivnější podobě přeshraniční spolupráce, je zde viděna jazyková bariéra a nedostatek aktérů, kteří by vyvíjeli aktivitu a komunikovali s podobnými angažovanými jedinci na druhé straně hranice. To má za následek, že se ve studovaném území nepodařilo vytvořit tzv. přeshraniční společenství. Obě části euroregionu, jak slovenská, tak rakouská, spolu nekomunikují dostatečně a orientují se zejména na své hlavní město, na Bratislavu nebo na Vídeň, a nikoliv na spolupráci se subjekty v sousedním státě.

Výzkum byl finančně podpořen programem Aktion CZ-AT rakouské agentury OeAD.

\section{LITERATURA}

BAHNA, M. (2009). Pracovná migrácia zo Slovenska po vstupe do EÚ v kontexte krajín $E U^{\prime}$, [Online]. Dostupné na: http://www.sociologia.sav.sk/cms/uploaded/ 1216 attach Pracovna_migracia_zo_Slovenska_v kontexte_EU 10.pdf [cit: 27-11-2015].

BENČ, V., BILČÍK, V., DULEBA, A., GRŪBER, T, ST̄RÁZ̆AY, T. (2013). Dve dekády slovensko-rakúskych vzt’ahov. Bratislava (Výskumné centrum Slovenskej spoločnosti pre zahraničnú politiku, Vel'vyslanectvo Rakúskej republiky v Slovenskej republike AEPress, s.r.o.).

CIZEK, CH. (2010). Die grenzüberschreitende Zusammenarbeit zwischen dem nördlichen Waldviertel und Südböhmen - Chancen für die Grenzstadt Gmünd/České Velenice, Diplomarbeit, Universität Wien, Wien.

ČESKÝ STATISTICKÝ ÚŘAD (2015). Euroregion Pomoraví, [Online]. Dostupné na: http://www.czso.cz [cit. 20-7-2017].

DOKOUPIL, J., MATUŠKOVÁ, A., ROUSOVÁ, M., PREIS, J., KAŇKA, L. (2012). Euroregion Sumava. Plzeň (Aleš Čeněk).

DRGONA, V. (2001). Euroregióny - nový prvok regionálnej štruktúry Slovenskej republiky a Mad'arskej republiky. In Novák, S. ed. Geografické aspekty stredoevropského prostoru. Brno (Masarykova univerzita), pp. 26-30.

FALŤAN, L., ed. (2003). Mentálna hranicalobraz suseda v slovensko-rakúskom pohraničí. Bratislava (Sociologický ústav SAV).

FASSMANN, H., MÜNZ, R. (2002). EU enlargement and future east-west migration. In Laczko, F., Stacher, I., Klekowski von Koppenfels, A., eds. New challenges for migration policy in Central and Eastern Europe. Hague (T.M.C. Asser Press and International Organisation for Migration), pp. 59-86.

FRIDRICH, CH., ZLOCHOVÁ, K. (2009). Das österreichisch-slowakische Grenzgebiet. Ausgewählte humangeographische und physiogeographische Aspekte. In Hitz, H., Wohlschlägl, H., eds. Das östliche Österreich und benachbarte Regionen. Ein geographischer Exkursionsführer. Wien-Köln-Weimar (Böhlau Verlag), pp. 421-442.

HALÁS, M. (2005). Cezhraničné väzby, cezhraničná spolupráca: na príklade slovenskočeského pohraničia s dorazom na jeho slovenskú čast'. Bratislava (Univerzita Komenského v Bratislave).

HALÁS M., SLAVÍK, V. (2001). Cezhraničná spolupráca a euroregióny v SR (ciele, realita, perspektivy). Miscellanea Geographica, 9. 171-180. 
HAVLÍČEK, T. (1999). Die Wiederbesiedlung der ehemals von Deutschen besiedelten Randgebiete der Tschechischen Republik nach 1945. Erzieherbrief der AGSLE, Jg., 46, $3-10$.

JEŘÁBEK, M., DOKOUPIL, J., HAVLÍČEK, T. (2004). České pohraniči - bariéra nebo prostor zprostředkováni? Praha (Academia).

JERÁBEK, M., POKORNÁ, A., ŠLAJCHRT, M. (2012). Euroregion Elbe/Labe - regionálni studie. Ústí nad Labem (UJEP).

JEŘÁBEK, M., HEINTEL, M., WEIXLBAUMER, N. (2017). Transformace pohraničí na př́kladu jihomoravského-dolnorakouského regionu. Ústí nad Labem (MINO).

KOLLÁR, D. (2001). Obraz Rakúska a Slovenska u obyvatel'ov slovensko-rakúskeho pohraničia. Geografický časopis, 53, 59-74.

KOWALKE, H., JERÁBEK, M., SCHMIDT, O., LOHSE, K. (2012). Otevřené hranice působení v česko-saském pohraničí. Acta Universitatis Purkynianae, 180. Ústí nad Labem (Univerzita J. E. Purkyně).

Land Niederösterreich/Zahlen und Fakten/Bildung (2015), [Online]. Dostupné na: http:// www.noe.gv.at. [cit: 20-7-2017].

MARTINEZ, O. J. (1994). The dynamics of border interaction. In Shofield, C., ed. Global boundaries. World boundaries, 1. London and New York (Routledge), pp. 1-15.

NOVOTNÁ, M., NAJMAN, J., BIČÍK, I. (2011). Změny ve využívání území na českobavorské hranici v období 1990-2006. In Dokoupil, J., Kopp, J., eds. Vliv hranice na prírodní a socioekonomické prostředí česko-bavorského pohraničí. Plzeň (Západočeská univerzita v Plzni), pp. 23-46.

PERKMANN, M. (2003). Cross-border regions in Europe. Significance and drivers of cross-border cooperation. European Urban and Regional Studies, 10, 153-171.

PISCOVÁ, M. (1997). A spekty národnej identity a národná identita v strednej Európe. Bratislava (Sociologický ústav SAV).

PLESKOT, I. (2005). Vliv zahraničních sousedů na zaměstnanost a nezaměstnanost v př́ihraničním pásmu ČR. In Zich, F., ed. Přeshraniční vlivy pưsobící na mistní společenství pohraniči České republiky. Ústí nad Labem (UJEP FSE), pp. 47-73.

PTÁČEK, P, OPRAVIL, Z., ROUBÍNEK, P., eds. (2015). Aktuální výzvy pro strategii česko-polského pohraničí: prŕípadová studie př́íhraničí euroregionu Praděd. Geographica Moravica 4. Olomouc (Univerzita Palackého v Olomouci).

REGIONALVERBAND EUROPAREGION WEINVIERTEL (2015), [Online]. Dostupné na: http://www.euregio-weinviertel.eu/ [cit. 27-9-2015].

SLAVIK, V. (2004). Cezhraničná spolupráca, euroregióny v SR a výskum ich doterajších aktivit. In Falt’an, L. ed. Regionálny rozvoj Slovenska v európskych integračných kontextech (Regióny, prihraničné regióny, euroregióny), NK UNESCO - Most. Bratislava (Sociologický ústav SAV), pp. 91-108.

SPISIAK, P. (2004). Geografické aspekty euroregiónov Slovenska (Bližší pohl'ad na NUTS II - Slovensko juhozápad a Euroregión Bíle-Biele Karpaty). In Faltan, L., ed. Regionálny rozvoj Slovenska v európskych integračných kontextech (Regióny, prihraničné regióny, euroregióny), NK UNESCO - Most. Bratislava (Sociologický ústav SAV), pp. 109130.

SIK, E., SURÁNYI, R. (2015). Cross-Border Migration and its Implications for the Central European Area. In Falt'an, L., ed. Cross-Border Migration and its Implications for the Central European Area. Bratislava (Sociologický ústav SAV), pp. 160-177.

ŠINDELÁR̆, M. (2016). Studie česko-rakouského pohraničí na území Euroregionu Pomoraví/Weinviertel. Regionální rozvoj mezi teorii a praxí, 1, 35-49.

ŠÚ SR (2015) Obyvatel'stvo Trnavského kraja, [Online]. Dostupné na: http://www. slovak.statistics.sk [cit. 20-7-2017].

VAISHAR, A., ČERMÁK, D., DVOŘ́K, P., NOSKOVÁ, H., STACHOVÁ, J., TOŠOVSKÁ, E., VAJDOVÁ, Z., ZAPLETALOVA, J. (2009). Orlicko - region v pohraničí. Studia geographica, 102. Brno (Ústav geoniky AV ČR). 
VAISHAR, A., ZAPLETALOVÁ, J. (2005). Marginalizace moravsko-slovenského pohraničí. In Novotná, M., ed. Problémy periferních oblastí. Praha (Univerzita Karlova), pp. 167-176.

WEIXLBAUMER, N. (1999). Die Grenze als Wahrnehmungsraum. Der österreichischslowakische Grenzraum nach 1989 - eine perzeptions-geographische Schauplatzchronologie. In Haslinger, P., ed. Grenze im Kopf. Beiträge zur Geschichte der Grenze in Ostmitteleuropa. Frankfurt am Main (Europäischer Verlag der Wissenschaften), pp. 183205.

ZICH, F., ed. (2003). Regionální identita obyvatel v pohraniči: Sborník přispěvků z konference „Evropská, národní ći regionální identita? “Praha (Sociologický ústav AV ČR).

Michal Šind e lár̆, Milan Je řábek

\section{THE SLOVAK-AUSTRIAN CROSS-BORDER COOPERATION IN INHABITANTS AND MAYOR'S OPINIONS}

The authors attempt to describe the cross-border cooperation between Slovakia and Austria and the changes which have occurred since the fall of the Iron Curtain in 1989 until now. The first part of the paper is focused on the establishment of the Pomoravi/ Weinviertel/Záhorie Euroregion. Furthermore, the development of relationships on both sides of the border is described.

The second part presents the results of a survey which was carried out in autumn 2016 with almost 400 respondents from both countries. The main topics of this research are population stability, the perception of Austria and of Slovakia by the locals and the activities of the Euroregion. The survey was supplemented with interviews with the mayors of selected municipalities in this borderland.

The findings show that the relations between Slovakia and Austria are perceived as quite good. The opening of the border is perceived positively as well. However, the intensity of cross-border cooperation is unfortunately rather low in comparison with the CzechAustrian borderland. The locals are satisfied with their lives in this region and the quality of the environment as well as the peacefulness of the area is positively evaluated. On the other hand, quite a high unemployment rate and few job vacancies (in Austria) and low salaries (in Slovakia) belong to the negative factors. Moreover, despite the growth of the Slovak economy, the economic convergence to Austria continues only very slowly. 